\title{
Impact of used motor oil on soil properties and yield indices of corn in Izzi, Ebonyi State, Nigeria
}

Nwite James Nte ${ }^{1 *}$,Enyioko Chimezie Onyeoziri², Nwogbaga Andrew Chukwuma ${ }^{3}$

${ }^{1}$ Department of Soil Science and Environmental Management, Ebonyi State University, PMB 053 Abakaliki, Nigeria

${ }^{2}$ Federal College of Land Resources Technology, Owerri, Imo State, Nigeria

${ }^{3}$ Department of Crop and Landscape Management, Ebonyi State University, PMB 053 Abakaliki, Nigeria

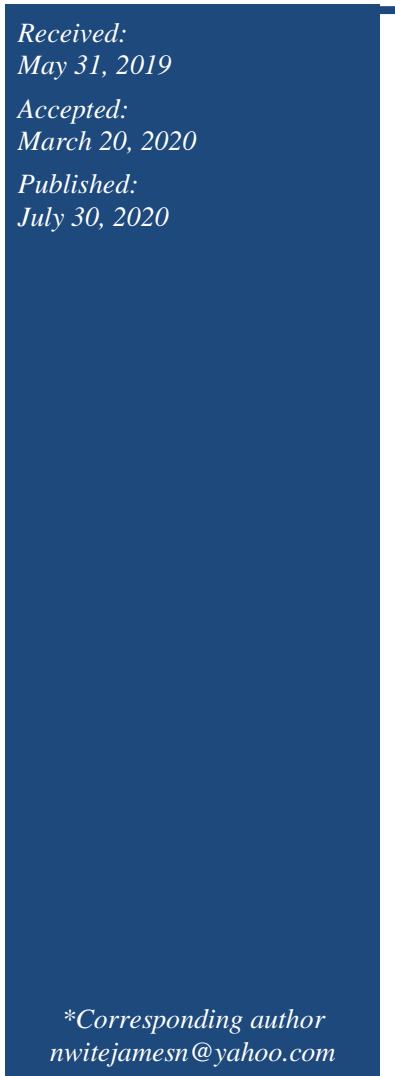

\begin{abstract}
A lot of used motor oil is drained into the soil annually. The possibility of establishing impacts of used motor oil on soil properties and corn yield was studied with treatments i.e. 0 (control), 0.5, 1.0, 1.5, 2.0\% for screen house and 0 (control), 8.0, 16.0, 24.0, $32.0 \%$ for field in demonstration farm of Ebonyi State University, Nigeria. The experiments were laid out using completely randomized design (CRD) and randomized completely block design (RCBD), with four replications having pot and plot dimensions of $30 \times 30 \mathrm{~cm}$ and $1.2 \times 1.2$, respectively. Uniform cultural practices were applied to all treatments. Statistical analysis was used to analyze soil and crop data. Results showed that application of treatments at 2.0 and $32.0 \%$ reduced gravimetric moisture content at significant $(\mathrm{P}<0.05)$ levels of 47 and $82 \%$ for the two studies. Available $\mathrm{P}$ was significantly reduced by 57 and $87 \%, \mathrm{~K}$ by 125 and $140 \%, \mathrm{~N}$ and $\mathrm{K}$ by 57 and $233 \%$ at 2.0 and $32.0 \%$ treatments compared to control. Crop yield indices were depressed at 400 and $150 \%$ at 2.0 and $32.0 \%$ treatments for dry matter and grain. Current study suggested that soil properties except $\mathrm{pH}$ and yield indices can be maximally degraded if used motor oil is applied at rates of 2.0 or $32.0 \%$ or minimally at 0.5 and $8.0 \%$.
\end{abstract}

Keywords: Motor oil, Soil properties, Yield indices, Corn

How to cite this:

Nwite NJ, Onyeoziri EC and Chukwuma NA, 2020. Impact of used motor oil on soil properties and yield indices of corn in Izzi, Ebonyi State, Nigeria. Asian J. Agric. Biol. 8(3):291-298. DOI: https://doi.org/10.35495/ajab.2018.08.263

This is an Open Access article distributed under the terms of the Creative Commons Attribution 3.0 License. (https://creativecommons.org/licenses/by/3.0), which permits unrestricted use, distribution, and reproduction in any medium, provided the original work is properly cited.

\section{Introduction}

Corn which is commonly known as maize (Zea mays L.) in Nigeria is a cereal crop and belongs to the family of grains referred to as gramineae. It is extensively cultivated in Subsahara Africa and third most important staple cereal food crop in Nigeria (NPAFS, 2010). Corn is rich in carbohydrate, protein and vitamins and a good source of dietary needs for both man and animals of all ages in different forms
(Anikwe et al., 2005). The crop is grown on all types of soils but performs optimally well on a rich well drained sandy loam lacking impervious layer before $30 \mathrm{~cm}$ depth (Harper, 1999). It does not tolerate high density soil which is often prone to drought and low stabilization. These kinds of soils encourage poor rooting, lodging and limit yield optimization. Soils which are high in fertility status especially NPK with some micronutrients are ideal for production of the crop, although can thrive under a low to medium 
fertility condition (Anikwe et al., 2005). It can yield well on a pH range of 5.0 - 5.8 (Mbah et al., 2010) but marginal yields are obtained on a poor soil with very strongly acidic condition. Good management practices can boost the production of the crop (Anikwe, 2015). It can be grown as a sole crop because of its excessive demand for nutrients and as a result, it is not a good fit for mixed culture (Harper, 1999). High performance is obtained under rotational cropping, but continuous cultivation and perhaps low input of amendments impede nutrients release and therefore adversely affect yield of the crop (NPAFS, 2010). More than half of corn and legume cultivated areas > $5.0 \mathrm{mha}^{-1}$ in Nigeria was subjected to contamination of used motor oil causing more than $30 \%$ annual yield reductions (Anon, 1985) while not $<100$ ha of arable lands were contaminated in Abakaliki leading to more than $15 \%$ yield losses of corn. The waste oil is injurious to soil health and quality if it gets into soil. Onwuka et al. (2012) reported that such oil reduced soil fertility and productivity with accompanied poor crop growth and yield (Odjegba and Sadiq, 2002). This is supported by report of Ogboghodo et al. (2001) which noted deterioration in bulk density, available water capacity and air circulation. According to Diana et al. (2004) there was poor nutrients expression as common characteristic of spent oil contaminated soil. For instance, Agbogidi and Enujeke (2012) noted that N, $\mathrm{P}, \mathrm{Ca}, \mathrm{Mg}$ and $\mathrm{K}$ were low in contaminated soil relative to uncontaminated soil. This was corroborated by Kayode et al. (2009) which noted its positive influence on some chemical properties of soil. The increase in soil density coupled with low aeration and moisture content naturally can affect fertility of soil as well as crops potential to access nutrients. In support Obi (2000) observed that physical and chemical properties synergize for optimal crop yield. The present research was conducted with the following objectives: (1) to find out impact of used motor oil on soil properties (2) to assess yield indices of corn under different experimental conditions. Profitable corn production in Nigeria demands good and fertile soil lacking physical and chemical impediments. This lack of agreement has cast doubt on clear trend of impact of used motor oil on soil productivity and, therefore needs more investigation.

\section{Material and Methods}

The experiments were carried out in demonstration farm of Soil Science Research Ebonyi State University for two consecutive years to find impact of used motor oil on soil environment under different conditions. Composite soil samples were collected from $0-20 \mathrm{~cm}$ depth at the same site for field study before commencing the study. The soil samples were air dried, ground and passed through $2 \mathrm{~mm}$ sieve and thereafter analyzed for physicochemical properties (Table-1).

Table-1. Soil properties before planting

\begin{tabular}{|c|c|}
\hline Soil properties & Value \\
\hline Sand $\mathrm{gkg}^{-1}$ & 560 \\
\hline Silt gkg-1 & 240 \\
\hline Clay gkg ${ }^{-1}$ & 200 \\
\hline Texture & Sandy loam \\
\hline $\mathrm{pH} \mathrm{KCl}$ & 5.6 \\
\hline Available-P mgkg $^{-1}$ & 26.10 \\
\hline Nitrogen gkg $^{-1}$ & 0.10 \\
\hline Organic-C gkg ${ }^{-1}$ & 1.05 \\
\hline Organic matter gkg $^{-1}$ & 1.81 \\
\hline Cacmolkg $^{-1}$ & 2.40 \\
\hline Mgcmolkg $^{-1}$ & 1.20 \\
\hline $\mathrm{Kcmolkg}^{-1}$ & 0.08 \\
\hline Nacmolkg $^{-1}$ & 0.21 \\
\hline CECcmolkg $^{-1}$ & 43.71 \\
\hline Exchangeable acidity cmolkg $^{-1}$ & 0.48 \\
\hline Base saturation $\%$ & 89 \\
\hline Bulk density $\mathrm{gcm}^{-3}$ & 1.23 \\
\hline Total porosity $\%$ & 53 \\
\hline Hydraulic conductivity $\mathrm{cmhr}^{-1}$ & 83.80 \\
\hline Gravimetric moisture content $\%$ & 24 \\
\hline Aggregate stability $\%$ & 52 \\
\hline
\end{tabular}

Sieved composite soil sample also collected from the site and weighing $30 \mathrm{~kg}$ was transferred to perforated plastic pots with dimensions of $30 \mathrm{~cm} \times 30$. The pots were arranged in completely randomized design (CRD) with $0.5 \mathrm{~m}$ spaces among the pots and $1 \mathrm{~m}$ alleys separating the four replications. Used motor oil was collected from mechanic village. The treatments were 0 (control), $0.5,1.0,1.5$ and $2.0 \%$. The used motor oil was applied and incorporated according to the treatments plan 14 days before planting corn seeds at $15 \mathrm{~cm}$. Two weeks after germination, seedlings were thinned down to one stand per hole leaving approximately 44,444 plants per ha ${ }^{-1}$. Lost stands were replaced through replanting for optimal population. Fertilizer (NPK) in a ratio of 30:20:15 was applied at $400 \mathrm{~kg} \mathrm{ha}^{-1}$ in a single dose on each pot immediately 
after thinning. The pots were watered adequately. The pot study was extrapolated to field condition. The vegetation in the site was slashed and removed. A land area of 0.35 ha was used for the experiment which was designed using randomized complete block design (RCBD) with plot sizes of $1.2 \times 1.2 \mathrm{~m}$ separated by 0.5 $\mathrm{m}$ apart. Equivalent treatments of 0 (control), 8.0, $16.0,24.0$ and $32.0 \%$ having four replications were applied according to design and incorporated into the soil 14 days before planting corn seeds at a distance of 25 x $75 \mathrm{~cm}$. Fertilizer (NPK) at a formulation ratio of 30:20:15 was applied at $400 \mathrm{kgha}^{-1}$ on each plot in a single dose. The seedlings were thinned down to one stand in each hole while the lost ones were replaced to give 53,333 corn stands ha ${ }^{-1}$. Weeds were controlled manually by hand as often as they appeared. The corn hybrid resists pesticide disease attack.

The core and auger soil samples were collected from each pot and plot at $0-20 \mathrm{~cm}$ depths after harvest for assessment of physical and chemical properties. Auger samples were dried, ground and sieved with $2 \mathrm{~mm}$ sieve before determination of chemical parameters. At maturity, dry matter yield was obtained from corn plants in each pot after uprooting, washing of roots of soil particles and drying. Grain yield was assessed after harvesting the cob by removing the husks, detaching grains from cobs and drying to $14 \%$ moisture content. The used motor oil was analyzed for chemical composition according to Benka-Coker and Ekundayo (1995) (Table 2).

Table-2. Some properties of treatment

\begin{tabular}{|l|c|}
\hline Nutrient composition & Value \\
\hline Available-P mgkg- & 9.50 \\
\hline Organic-C gkg-1 & 7.98 \\
\hline $\mathrm{Ngkg}^{-1}$ & 0.58 \\
\hline $\mathrm{C}: \mathrm{N} \mathrm{ratio}^{-1}$ & 13.76 \\
\hline $\mathrm{Cu} \mathrm{gkg}$ & 15.70 \\
\hline $\mathrm{Zn} \mathrm{gkg}^{-1}$ & 0.28 \\
\hline
\end{tabular}

Particle size distribution, total porosity, gravimetric moisture content, bulk density and hydraulic conductivity were determined using Obi (2000) method. Soil particles $<4.76 \mathrm{~mm}$ were assessed using sieving technique of Kemper and Rosenau (1986) for aggregate stability. Soil $\mathrm{pH}$ was determined in 1:2.5 soil and water solution ratio using electronic $\mathrm{pH}$ meter (Peech, 1965), organic-C by Walkley and Black method of Nelson and Sommer (1982), total-N extracted using microkjeldhal distillation method (Bremner, 1996) and $\mathrm{Ca}, \mathrm{Mg}, \mathrm{K}, \mathrm{Na}$ and $\mathrm{CEC}$ were extracted with atomic absorption spectrophotometer (Ohiri and Ano, 1988) and flame photometer after using $1 \mathrm{~N} \mathrm{NH}_{4} \mathrm{CH}_{3} \mathrm{CO}_{2}$. All data from soil and crop were processed for statistical analysis according to SAS (1985) and means separated with Fisher's Least Significant Difference.

\section{Results and Discussion}

\section{Impact of used motor oil on soil properties Soil texture}

Texture plays vital role on general behaviour of soil with regards to nutrients sorption-desorption, plantwater relation, aeration as well as plants root anchorage. The type of soil texture depends on properties of the three separates of sand, silt and clay. If the proportion of sand is excessively higher than other fractions, the soil will be coarse textured and lack coherence. Nutrients and mechanical anchorage will be jeopardized (Akamigbo, 2010). The particle sizes varied between pre and post planting, but this variation did not affect the texture of the soil. The sand fraction remained predominantly higher even after plantings yielding sandy loam texture. The application of treatment may have caused particle size redistribution (Table 3) but did not change texture. Adesodun (2004) obtained redistribution of particle sizes in his investigation but texture remained unchanged after waste oil treatment. This finding is in support of Obi (2000) observation that cultural practices including temporary soil management did not change soil texture. Okonokhua et al. (2007) also observed non-effect of waste oil application on soil texture. Texture recorded in this work could be attributed to parent material of soil rather than impact of treatment. Although texture was not changed from recorded initial data, it could be changed if there is continuous application of the treatment.

\section{Bulk density (BD) and total porosity (TP)}

The bulk density of soil is dependent upon soil texture, structure, presence of organic substances and clay fractions in the soil. Impact of treatment is measured on increase or decrease of this soil parameter. High values of BD suggest more dense, hard and compact soil that is low in porosity. Essentially, normal soil should have lower bulk density than its equivalent contaminated soil. The bulk densities of treated soil were significantly $(\mathrm{P}<0.05)$ higher except the one that received $8.0 \%$ of used motor oil under field condition giving highest $\left(1.42\right.$ and $\left.1.46 \mathrm{gcm}^{3}\right)$ values for highest 
(2.0 and 32.0\%) treatments. The result of BD in Table 3 indicates compaction of soil due to impact of used motor oil which was $11-13 \%$ significantly higher for the treatments of 2.0 and $32.0 \%$ compared to control. The resultant impact of higher bulk densities was reduction in total porosities when compared to control for both experiments. This decrease of porosities (47and 45\%) was more pronounced with highest rates of treatments (Table 3). Contamination of soil with hydro carbon oil cause undesirable change in physical properties such as bulk density and total porosity (Ogboghodo et al., 2001.) Increased bulk density as well as reduction in soil porosity with use of waste oil were obtained by Mbah et al. (2010). Interestingly, these parameters were not at critical levels for soil productivity (Anikwe, 2006).

\section{Hydraulic conductivity (HC) and gravimetric moisture content (GMC)}

The importance of hydraulic conductivity is its relationship with soil-plant relations and in reclamation of soil. If water cannot permeate into lower profile, distribution of nutrients and other particles becomes difficult and would reduce efficiency of crops in utilization of mineral elements. The rate of water conductivity in soil has influence on its moisture content. Gravimetric moisture content can be affected by amount and type of clay content, organic matter, texture and structure. Soil initial data showed higher values of HC and GMC which were $83.80 \mathrm{cmhr}^{-1}$ and $24 \%$, respectively. After treatment, there were significant reductions compared to control for the two conditions (Table 3). Maximum decreases were $72.93 \mathrm{cmhr}^{-1}$ and $15.0 \%$ as well as $0.29 \mathrm{cmhr}^{-1}$ and $11.0 \%$ resulting to $14-47 \%$ and $58-82 \%$ significant reductions in hydraulic conductivity and gravimetric moisture content when 2.0 and $32.0 \%$ of used motor oil were applied. The increase in soil density and decrease in porosity resulted to low significant $\mathrm{HC}$ and GMC (Table 3). Similar findings have been reported in significant low permeability of soil and moisture content due to treatment of waste oil (Agbogidi and Enujeke, 2012). The results confirm earlier observations of Ogboghodo et al. (2001) that hydrocarbon oil application reduced hydraulic conductivities and gravimetric moisture content capacities of soil.

\section{Aggregate stability (AS)}

Aggregate stability is a soil parameter which is an index for measurement of cohesiveness, dispersion, collapse and ability to withstand disruptive forces such as erosion. It plays great role in soil strength, nutrients retention and water storage. Compared to initial and control data, results showed significant reductions in the soil parameter at post-harvest studies.

Table-3. Impact of treatment on soil physical properties

\begin{tabular}{|c|c|c|c|c|c|c|c|c|c|}
\hline \multicolumn{10}{|c|}{$\longleftarrow$ gkg $^{-1} \longrightarrow$} \\
\hline Treatment & Sand & Silt & Clay & Texture & $\mathrm{BD}\left(\mathrm{gcm}^{-3}\right)$ & $\mathbf{T P}(\%)$ & $\mathrm{HC}\left(\mathrm{cmhr}^{-1}\right)$ & $\operatorname{GMC}(\%)$ & AS (\%) \\
\hline \multicolumn{10}{|c|}{ Pot experiment } \\
\hline Control & 550 & 250 & 200 & SL & 1.24 & 50 & 82.95 & 22.0 & 52.0 \\
\hline $0.5 \%$ & 560 & 240 & 200 & SL & 1.32 & 49 & 81.55 & 20.0 & 42.0 \\
\hline $1.0 \%$ & 570 & 200 & 220 & SL & 1.37 & 48 & 80.86 & 18.0 & 38.0 \\
\hline $1.5 \%$ & 580 & 210 & 210 & SL & 1.37 & 48 & 75.92 & 16.0 & 36.0 \\
\hline $2.0 \%$ & 580 & 220 & 210 & SL & 1.42 & 47 & 72.93 & 15.0 & 30.0 \\
\hline FLSD $(\mathrm{p}<0.05)$ & & & & & NS & NS & 0.82 & 2.0 & 3.0 \\
\hline \multicolumn{10}{|c|}{ Field Experiment } \\
\hline Control & 540 & 230 & 160 & SL & 1.30 & 48 & 17.00 & 20.0 & 42.0 \\
\hline $8.0 \%$ & 530 & 230 & 240 & SL & 1.30 & 48 & 15.00 & 18.0 & 30.0 \\
\hline $16.0 \%$ & 550 & 220 & 230 & SL & 1.40 & 47 & 0.83 & 15.0 & 25.0 \\
\hline $24.0 \%$ & 540 & 225 & 225 & SL & 1.46 & 45 & 0.57 & 13.0 & 22.0 \\
\hline $32.0 \%$ & 570 & 210 & 220 & SL & 1.46 & 45 & 0.29 & 11.0 & 18.0 \\
\hline FLSD $(p<0.05)$ & & & & & 0.07 & NS & 0.20 & 1.0 & 2.0 \\
\hline
\end{tabular}

BD - bulk density, TP - Total porosity, HC - hydraulic conductivity, AS - aggregate stability, GMC - gravimetric moisture content, SL - sandy loam, NS - not significant. 
Severity of impact of treatment was obtained at 2.0 and $32.0 \%$ application. Significantly higher reductions as much as 30.0 and $18.0 \mathrm{~mm}$ in AS representing 67 and $133 \%$ were recorded for the highest rates of applications for the conditions. Low AS observed could have been due to negative impacts of used motor oil on other physical properties of soil such as bulk density, total porosity and water characteristics (Table 3). Similar significant reduction in AS was recorded in a study carried out using hydrocarbon oil (Ogboghodo et al., 2001). Low stabilization of soil can impede nutrients adsorption and release, increase its vulnerability to collapsing forces and moisture stress (Anikwe, 2006).

\section{Soil pH}

Soil $\mathrm{pH}$ is one parameter that determines prevalence of ions, quality of soil or health and general management of soil. Initial soil data (Table 1) showed slightly acidic (5.6) condition. Soil $\mathrm{pH}$ in the two investigations ranged from significantly $(\mathrm{P}<0.05)$ slightly to strongly acidic conditions. More significantly improved $\mathrm{pH}$ was obtained in pot study (Table 4). Maximum increments of 11 and $17 \%$ in $\mathrm{pH}$ were recorded for 2.0 and $32.0 \%$ applications of waste oil relative to control. The treatment had significant positive impact on soil $\mathrm{pH}$ especially under pot experiment (Table 4). This could have been facilitated by improved exchangeable basses and CEC when compared to initial values (Table 1). Calcium and $\mathrm{Mg}$ in soil remove hydrogen ion or hydroxyl ion and cause them not to form complex with $\mathrm{Al}$ or Fe oxide (Mbah et al., 2010). From current study, application of used motor oil did not cause serious deleterious impact on soil $\mathrm{pH}$. This finding is supported by report of Amadi et al. (1996) that contamination of soil with spent oil significantly increased $\mathrm{pH}$. However, results obtained tend to reject the earlier observation of Okonokhua et al.(2007) that application of waste oil did not have any effect on soil $\mathrm{pH}$. It could be deduced that treatment of used motor oil is more pervasive on soil $\mathrm{pH}$ under field condition than controlled environment. Improved organic-C and $\mathrm{CEC}$ particularly could have been responsible for the higher $\mathrm{pH}$ recorded in pot experiment (Table 4).

\section{Available P}

This soil parameter plays great role in crop nutrition and maturity. If soil $\mathrm{pH}$ is low, $\mathrm{P}$ becomes fixed by $\mathrm{Al}$ or Fe by forming complex and in that way will not be available (Kolay, 2013). At pre-planting, data presented $\left(6.10 \mathrm{mgkg}^{-1}\right)$ medium $\mathrm{P}$ which was reduced at post-harvest. Minimum significant reductions occurred at $0.5 \%\left(0.08 \mathrm{mgkg}^{-1}\right)$ and $8.0 \%\left(12.6 \mathrm{mgkg}^{-}\right.$ $\left.{ }^{1}\right)$ relative to control. These accounted for 38 and $33 \%$ depressions in $\mathrm{P}$ for the two studies. Whereas, maximum reductions were recorded at $2.0 \%(0.07$ $\left.\mathrm{mgkg}^{-1}\right)$ and $32.0 \%\left(9.0 \mathrm{mgkg}^{-1}\right)$ which translated to 57 and $87 \%$ significant depressions in $\mathrm{P}$ relative to control for the two studies. Generally, there were significant reductions in all oil treated soil for the two experiments with respect to control. Reduction was more severe in pot than field condition. Results confirm significant reductions in available $\mathrm{P}$ in soil (Kayode et al., 2009) after application of waste oil. Variations shown in available $\mathrm{P}$ between pot and field studies could be attributed to prevailing conditions in each study. The parameter was reduced from low to critical values at post planting (FMARD, 2002).

\section{Nitrogen $(\mathrm{N})$ and organic carbon (OC)}

Organic-C (OC) is very important index for assessment of soil for fertility status and productive capacity. It controls soil exchange complex, buffer capacity as well as availability of $\mathrm{N}$. The initial level of OC in soil was medium $\left(1.05 \mathrm{gkg}^{-1}\right)$ which indicated that it was unsatisfactory for crop growth and yield. The reductions in $\mathrm{OC}$ significantly $(\mathrm{P}<0.05)$ varied from pot to field experiment relative to control recording (2.14 and $\left.0.36 \mathrm{gkg}^{-1}\right)$ which were 23 and 56\%incrementsfor 2.0 and $32.0 \%$ treatments. These values ranged from critical to high after post planting. Initial data (Table 1) for $\mathrm{N}$ was very low. Results after treatment further showed significant very low values for $\mathrm{N}$ in all oil treatments compared to control. Minimal values of 0.07 and $0.03 \mathrm{gkg}^{-1}$ were recorded at 2.0 and $32.0 \%$ which represented 57 and $233 \%$ reductions of $\mathrm{N}$ for the treatments. Results from this study support the report of Agbogidi et al. (2006) and Diana et al. (2004) that waste oil contamination reduced $\mathrm{N}$ and $\mathrm{OC}$.

Low $\mathrm{N}$ and $\mathrm{OC}$ in waste oil treatment can as well be linked to nutrition of crops (Anikwe et al., 2005) and dynamics of soil. Appreciable levels of OC in pot experiment than field could be due to higher $\mathrm{pH}$ values observed in the controlled environment (Table 4) and this was corroborated by Kolay (2013). 
Nwite James Nwite et al.

Table-4. Impact of treatment on chemical properties of soil

\begin{tabular}{|c|c|c|c|c|c|c|c|c|}
\hline & & $\longleftarrow$ & $\mathrm{Cm}$ & $\mathrm{kg}^{-1}$ & $\rightarrow$ & & & \\
\hline Treatment & pH(kcl) & $P\left(\mathrm{mgkg}^{-1}\right)$ & $\mathrm{N}(\%)$ & $\mathrm{OC}(\%)$ & $\mathbf{C a}$ & Mg & $\mathbf{K}$ & CEC \\
\hline & & & Po & xperimen & & & & \\
\hline Control & 5.9 & 0.11 & 0.11 & 2.73 & 5.2 & 3.6 & 0.12 & 92.28 \\
\hline $0.5 \%$ & 6.2 & 0.08 & 0.07 & 2.46 & 4.8 & 3.2 & 0.11 & 83.98 \\
\hline $1.0 \%$ & 6.3 & 0.08 & 0.06 & 2.59 & 4.4 & 2.8 & 0.09 & 68.45 \\
\hline $1.5 \%$ & 6.0 & 0.07 & 0.08 & 2.30 & 4.0 & 2.6 & 0.08 & 76.42 \\
\hline $2.0 \%$ & 6.6 & 0.07 & 0.07 & 2.14 & 3.2 & 1.6 & 0.05 & 57.49 \\
\hline FLSD $(\mathrm{P}<0.05)$ & 0.2 & 0.01 & 0.01 & 0.20 & 0.2 & 0.1 & 0.01 & 0.06 \\
\hline & & & Fic & experim & & & & \\
\hline Control & 5.0 & 16.8 & 0.10 & 0.56 & 4.8 & 2.8 & 2.74 & 79.27 \\
\hline $8.0 \%$ & 5.3 & 12.6 & 0.08 & 0.40 & 3.2 & 2.7 & 0.13 & 77.85 \\
\hline $16.0 \%$ & 5.6 & 10.5 & 0.06 & 0.44 & 4.4 & 2.4 & 0.14 & 77.35 \\
\hline $24.0 \%$ & 5.8 & 9.5 & 0.06 & 0.40 & 4.2 & 2.2 & 0.14 & 71.67 \\
\hline $32.0 \%$ & 6.0 & 9.0 & 0.03 & 0.36 & 3.2 & 1.6 & 0.03 & 52.67 \\
\hline FLSD $(\mathrm{P}<0.05)$ & 0.1 & 0.1 & 0.03 & 0.01 & 0.4 & 0.5 & 0.17 & 0.04 \\
\hline
\end{tabular}

Exchangeable cations ( $\mathrm{Ca}, \mathrm{Mg}, \mathrm{K})$ and cation exchange capacity (CEC).

Exchangeable cations and CEC are important soil parameters. Cations influence soil $\mathrm{pH}$, exchange complex and coagulation. Soil data (Table 1) for $\mathrm{Ca}$, $\mathrm{Mg}, \mathrm{K}$ and $\mathrm{CEC}$ indicated low values. These values appreciated in all treatments at harvest compared to initial data although not significant except control for the experiments. The lowest values $(3.2,1.6$ and 0.05 $\left.\mathrm{cmolkg}^{-1}\right)$ for $2.0 \%$ and $\left(3.2,1.6\right.$ and $\left.0.03 \mathrm{cmolkg}^{-1}\right)$ for $32.0 \%$ were respectively recorded for $\mathrm{Ca}, \mathrm{Mg}$ and $\mathrm{K}$ for the studies. These accounted for respective 63 , $125,140 \%$ and $50,75,9033 \%$ reductions in $\mathrm{Ca}, \mathrm{Mg}$ and $\mathrm{K}$ for the two studies compared to control. Similar results of significant reductions in CEC were obtained relative to untreated soil for both experiments. However, higher CEC (61\%) at $2.0 \%$ and $51 \%$ at $32.0 \%$ rates of treatments were observed with respect to control. Significantly reduced values of exchangeable $\mathrm{Ca}, \mathrm{Mg}, \mathrm{K}$ and $\mathrm{CEC}$ were recorded due to application of soil with lubricant oil (Uchegbu et al., 2012). Impact of treatment indicated more severity as rates of applications increased which culminated with highest rates. These findings tend to support report of Amadi et al. (1996) for exchangeable cations and CEC in a similar study.

\section{Impact of used motor oil on yield indices}

Yields data of crops are direct measures of soil conditions, climatic and type of varieties, as well as cultural practices. First and foremost, ideal physical and chemical soil conditions are pre-requisite for seed germination, establishment and growth which is linked with the rhizospheric condition faced by the crop plant. Healthy growth determines good and economical yield. The results showed a lower yield indices following application of treatment on soil as it was the main reason for increasing soil density and decreasing porosity, moisture content as well as conductivity and chemical properties with the exception of $\mathrm{pH}$ in controlled study. Dry matter and grain yield data (Table 5) significantly decreased with application of treatment compared to untreated soil, respectively. Highest negative impacts of treatments were evidenced at 2.0 and $32.0 \%$ (Table5). Thus, there were 400 and $150 \%$ reductions in dry matter and grain yields over control (Table 5).

Table-5. Impact of treatment on yield indices

\begin{tabular}{|c|c|c|c|}
\hline Treatment & $\begin{array}{c}\text { Dry matter } \\
\left(\text { gplot }^{-1}\right)\end{array}$ & Treatment & $\begin{array}{c}\text { Grain yield } \\
\left(\text { (ha }^{-1}\right)\end{array}$ \\
\hline Control & 25.0 & Control & 2.5 \\
\hline $0.5 \%$ & 18.0 & $8.0 \%$ & 2.0 \\
\hline $1.0 \%$ & 15.0 & $16.0 \%$ & 1.5 \\
\hline $1.5 \%$ & 9.0 & $24.0 \%$ & 1.3 \\
\hline $2.0 \%$ & 5.0 & $32.0 \%$ & 1.0 \\
\hline FLSD $(\mathrm{P}<0.05)$ & 5.0 & FLSD $(\mathrm{P}<0.05)$ & 0.5 \\
\hline
\end{tabular}

All other rates of treatments were inferior. Consequent upon poor physical properties and low nutrients, significantly decreased yields obtained were not surprising. Studies conducted (Rainbow, 2007; Adeoye et al., 2005) on spent oil contaminated soil gave similar results of significant low maize yields. 
Odjegba and Sadiq (2002) had earlier revealed that crop yields indices were significantly low as a result of hydrocarbon oil application. The significant reductions in maize yield indices were attributed to low utilization of nutrients (Aulakh et al., 2007).

\section{Conclusion}

One good management approach to sustain soil quality and/or health and maintain its productive capacity is not to introduce any contaminant. Contamination of soil is not beneficial in any condition as the short comes outweigh some seemed advantages. Contamination at any level proved to be deleterious as it increased bulk density, reduced porosity, moisture content and conductivity, aggregate stability and nutrients availability. As a result, the dry matter and grain yields of corn significantly decreased with the deterioration of soil quality. The knowledge left for farmers and other stakeholders from this experiment is that they do not have to contaminate their soils which productive capacity can be degraded to critical limit if they apply used motor oil under controlled condition at full rate $\left(2.0 \%\right.$ pot $\left.^{-1}\right)$ or open field environment $\left(32.0 \%\right.$ plot $\left.^{-1}\right)$.

\section{Disclaimer: None.}

Conflict of Interest: None.

Source of Funding: None.

\section{References}

Adeoye GO, Sridhar MKC, Adeoluwa OO and Akinsoji NA, 2005. Evaluation of naturally decomposed solid wastes from municipal dumpsites for their manurial value in Southwest Nigeria. J. Sust. Agric. 26(6): 142-152.

Adesodun JK, 2004. Bioremediation of an alfisol contaminated with spent oil and its quality assessment using micro-morphological analysis. $\mathrm{Ph} . \mathrm{D}$ Thesis, University of Nigeria, Nsukka, Nigeria.

Agbogidi OM, Nweke FU and Okechukwu EM, 2006. Yield Performance of five cultivars of Soybean (Glycine mac L. Merr.) as influenced by soil contaminated with crude oi. Nig. J. Trop. Agric. 8:303 -309 .

Agbogidi OM and Enujeke EC, 2012. Effects of spent motor oil on soil physicochemical properties and growth of Arachis hypogea L. Global J. Bio-Sci. Biotechnol. 1(7): 68-74.
Akamigbo FOR, 2010. Soils: Fundamental Methods of Soil Resource Survey, Classification, Interpretation and Application. University Press Publishers Ltd, Bookshop Bank Building Complex, University of Nigeria, Nsukka. pp. 153.

Amadi A, Abbey SA and Nma A, 1996. Chronic effect of Oil Spill on Soil Properties and Micro Flora of a Rainforest Ecosystem in Nigeria. Water, Air Soil Poll. 86:1-11.

Anikwe MAN, 2006. Soil quality assessment: A review of current research efforts. New generation books, New Generation Ventures Ltd, Enugu Southeast, Nigeria.pp. 1 - 208.

Anikwe MAN, 2015. Soil Management for enhanced crop productivity. Proceedings of the $57^{\text {th }}$ Annual General Meeting of the Association of Deans of Agriculture in Nigerian Universities (ADAN) Abakaliki. pp. 13-25.

Anikwe MAN, Mbah CN, Ezeaku PI and Onyia VN, 2005. Ecophysiology and Cultivation Practices of Arable Crops. New Generation Books, Shop 51, NnamdiAzikiwe Stadium Shopping Mall, Ogui Road Enugu, Nigeria. pp. 1-318.

Anon, 1985. Collection and disposal of oily waste in Nigeria. Report prepared by Rivers Renewal Institute (RRI) Nigeria Ltd for disposal committee on petroleum wastes. pp. $1-10$.

Aulakh MS, Garg AK and Kabba BS, 2007. Phosphorus accumulation, Leaching and residual effects on crop yields from long-term applications in the sub-tropics. Soil Use Manage. 23:417-427.

Benka-Coker MO and Ekundayo JA, 1995. Effects of an oil spill on soil physicochemical properties of a spill site in the Nigeria Delta of Nigeria. Environ. Monitor. Assessment. 36:93-104.

Bremner JM, 1996. Nitrogen Total. In D. L. Sparts, (ed). Methods of Soil Analysis. Chemical methods. Am. Soc. Agron. 5(3): 1085 - 1121.

Diana BR, Diane JK, Richard ET and James JG, 2004. Natural revegetation of hydrocarbon-contaminated soil in semi-arid grass lands. Canadian Bot.82: 22 - 30 .

Federal Ministry of Agriculture and Rural Development (FMARD), 2002. Fertilizer Use and Management Practice for Crops in Nigeria. In E.A Aduayi, V.O Chude, B.A. Adebusayi, G.O. Olyiwola (eds). Federal Fertilizer Department, Abuja, Nigeria. pp. 1-88.

Harper F, 1999. Principles of arable crop production. Blackwell Science Ltd. United Kingdom, University Press, Cambridge, UK.p.336. 
Kayode J, Oyedeji AA and Olowoyo O, 2009. Evaluation of the Effect of Pollution with Spent lubricant oil on the physical and chemical properties of soil. The Pacific J. Sci. Technol. 10(1): 387-291.

Kemper WD and Rosenau RC, 1986. Aggregate stability and size distribution. In: Klute, A (ed). Methods of Soil Analysis. American Society of Agronomy Madison, Wisconsin.

Kolay AK, 2013. Basic Concepts of Soil Science. $2^{\text {nd }}$ (ed). New Age International Publications Ltd, New Delhi, India. pp. 10-250.

Mbah CN, Nwite JN, Njoku C and Nweke IA, 2010. Response of Maize (Zea mays L.) to different rates of wood ash application in ultisol with organic wastes and its effect on acid ultisol in southeast Nigeria. Afr. J. Agric. Res. 5(7): 580-593.

National Programme for Agriculture and Food Security (NPAFS), 2010. Federal Ministry of Agriculture and Rural Development. Report on Agricultural Production Survey pp.1-76.

Nelson DW and Sommer LE, 1982. Total carbon, Organic carbon and Organic matter. In: Page AL (eds). Methods of soil analysis: chemical and Microbiological properties. Am. Soc. Agron. 2(2):320 - 328.

Obi ME, 2000. Soil Physics. In: A Compendium of Soil Physics. Atlanta Publishers, Nsukka, Nigeria. pp. 40-48.

Odjegba VJ and Sadiq AO, 2002. "The environmentalist" Effect of spent Engine oil on the growth parameters, chlorophyll and protein levels of Amaranthus hybridus L. J. Environ. Sci. 22(1): 23-28.

Ogboghodo AE, Osemwota JO and Choker JU, 2001. An assessment of the effect of crude oil pollution on soil properties; Germination and Growth of maize (Zea mays L.) by two crude types-forcados light (UQOC) and EBGVOS light (cheveron). In Proceedings of $26^{\text {th }}$ Annual conference, SSSN, 24-28 March 2001, Unical
Calabar. pp. 299-300.

Ohiri A and Ano AO, 1988. Determination of exchangeable cations. Laboratory Hand Book of the National Root Crop Research Institute Umudike, Umuahia. pp. 1-56.

Okonokhua BC, Ikhajiagbee B, Anoliefo HO and Emede TO, 2007. The effect of spent engine oil on soil properties and Growth of maize (Zea mays L.). J. Appl. Sci. Environ. Manage. 11(3): 147 - 152.

Onwuka MI, Chude VO and Ogwuegbe GC, 2012. Remediation of engine oil polluted soil using two of organic manure and their effects on maize growth. Nig. J. Soil. Sci. 22(2): 245 - 258.

Peech M, 1965. Hydrogen ion activity. In: Black, C. A. (ed). Methods for Soil Analysis. Am. Soc. Agron. 9(2): 914-926.

Rainbow RW, 2007. Integration of No-till and Precision Agricultural Technologies and Future challenges to Conservation Agriculture in Australia. World Assoc. Soil Water Conserv. 3(3): 223-246.

Statistical Analysis System (SAS), 1985. User's Guide, 1985. Statistical Analysis Systems institute, Inc. Cary, NC, USA.

Uchegbu FO, Akubugwo EI, Iweala EJ, Uhegbu OC, 2012. Impact of spent engine oil on soil and the growth of Zea mays L. seeds. Scientific J. Environ. Sci. 1(1): 1-8.

\section{Contribution of Authors}

Nwite NJ: Conceived idea, designed research methodology, conducted experiments, collected and analysed data wrote manuscript Onyeoziri EC: Helped in data collection, analysis and manuscript write up Chukwuma NA: Helped in data collection, analysis and manuscript write up 